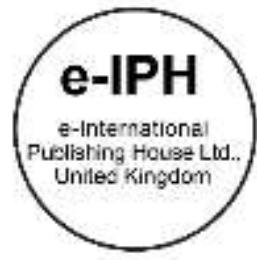

\title{
Tsurushibina Craft Story in the Context of Community Development: Inatori District of Higashiizu Town, Japan
}

\author{
Mariia Ermilova, Mitsunari Terada, Isami Kinoshita \\ Environmental Science and Landscape Architecture, Graduate School of Horticulture, \\ Chiba University, Japan \\ gboka.me@gmail.com, himitsukeychi@gmail.com, isamikinoshita@faculty.chiba-u.jp \\ Tel: +8108020883012
}

\begin{abstract}
Local craft production is considered one of the ways of sustainable community development, preserving the connection with the natural environment, contributing to economic, social and environmental sustainability. This study aims to investigate the origins of the traditional Japanese Tsurushibina decoration craft, as well as its connection to the natural environment, its history of origin, its preservation and use in the Inatori district. Finally, this study provides suggestions for further research of Tsurushibina decoration craft for sustainable local community development in contemporary setting.
\end{abstract}

Keywords: community development, sustainability, traditional craft, biocultural diversity

eISSN: 2398-4287 @ 2018. The Authors. Published for AMER ABRA cE-Bs by e-International Publishing House, Ltd., UK. This is an open access article under the CC BYNC-ND license (http://creativecommons.org/licenses/by-nc-nd/4.01. Peer-review under responsibility of AMER (Association of Malaysian Environment-Behaviou Researchers), ABRA (Association of Behavioural Researchers on Asians) and cE-Bs (Centre for Environment-Behaviour Studies), Faculty of Architecture, Planning \& Surveying, Universiti Teknologi MARA, Malaysia.

DOI: https://doi.org/10.21834/e-bpj.v3i8.1416

\subsection{Introduction}

An economically developed country, Japan is now facing the social problems of an aging society and rapid depopulation (Statistics Bureau of Japan, 2017). These social factors have a great impact on the local level, challenging communities to survive and preserve their heritage (Honda, Ueda, Ozaki, Inachi, \& Sakaki, 2015). At the same time, younger population migration to big cities and avoidance of living with the family leads to a decrease of traditional environmental knowledge, transmitted from older to younger generations, resulting in disconnection of younger generation with the landscape and inability to manage it (Tsuchiya, Aoyagi, Okuro, \& Takeuchi, 2014).

\subsection{Literature review}

\subsection{Biocultural diversity}

The connection between local culture, language and environmental knowledge, can result in the ability to manage the local environment. This occurrence received the attention of scientists and developed into the "biocultural diversity" field (Maffi \& Dilts, 2014). This concept links the preservation of local culture with the environmental sustainability of an area (Moro, 2016), (Chang, 2015). On the international policy level, the Joint Program between UNESCO and the Convention on Biological Diversity Secretariat (SCBD) was developed at the International Conference on Biological and cultural Diversity, held in Montreal, Canada in 2010 with objectives to "promote the collection,

eISSN: 2398-4287@ 2018. The Authors. Published for AMER, ABRA \& cE-Bs by e-International Publishing House, Ltd., UK. This is an open access article under the CC BYNC-ND license (http://creativecommons.org/licenses/by-nc-nd/4.0/). Peer-review under responsibility of AMER (Association of Malaysian Environment-Behaviour Researchers), ABRA (Association of Behavioural Researchers on Asians) and cE-Bs (Centre for Environment-Behaviour Studies), Faculty of Architecture, Planning \& Surveying, Universiti Teknologi MARA, Malaysia.

DOI: https://doi.org/10.21834/e-bpj.v3i8.1416 
compilation and analysis of information from on-the ground activities linking biological and cultural diversity from... local communities" and "raise awareness about the importance of biological and cultural diversity in resource management and decision-making processes as well as for the resilience of socioecological systems." This paper is contributing to both of these goals, firstly, describing the traditional craft of Tsurushibina as a biocultural phenomenon and secondly, investigating the role of it in the local community development.

\subsection{Traditional environmental knowledge and craft}

The term traditional knowledge (TK) includes a variety of knowledge, skills and practices that are developed, sustained and passed on from generation to generation within a community. Traditional Environmental Knowledge received a recognition as important for sustainable environmental management (Berkes, Colding, \& Folke, 2000). There are efforts to maintain and promote TK in Japan (Cetinkaya, 2009). The term "heritage" underlines the value of an information while the word "knowledge" underlines its applicability and utility to some life domain. There are similar terms, describing the category of traditional knowledge (TK) as an "intangible heritage" (by UNESCO), or "traditional cultural expressions" (TCEs), which includes crafts (World Intellectual Property Organization, 2017). Traditional crafts are expressions of the wisdom people gain from living in an environment and having a connection to nature through the use of local materials for the craft (MacEachren, 2000), (Egizbayeva \& Zhumatayev, 2014). Therefore, maintaining the crafts contributing to sustaining the environmental knowledge.

\subsection{Craft's contribution to sustainability}

Traditional craft can serve as a base for innovation and contribute to sustaining the genius loci (Shuaib \& Enoch, 2014), (Denan, Majid, \& Arifin, 2015), connecting with cultural identity (Silah, Basaree, Isa, \& Redzuan, 2013), and business development (Dragin, Krusmetra, Jeroscenkova, Pivac, \& Rivza, 2015). Women's crafting activities in an aging society proved to have a positive impact in social sustainability, contributing to such dimensions like social capital, participation, capacity building, or healthy aging (Maidment \& Macfarlane, 2011), (Tzanidaki \& Reynolds, 2011).

\subsection{Origination of Tsurushibina craft for Girls Day celebration}

Multiple cultural elements, including the writing system were borrowed by Japan from China, as well as Kanpoyaku - herbal medicine which literally translates as Chinese medicine. On this basis, Japan developed its own unique culture. This also relates to many traditions, including Girls Day, which is believed to originated in China, as a purification ceremony, when girls created the dolls and put them in the water stream. Since that time, it's evolved into a celebration with beautiful dolls, destined to be displayed, rather than to be disposed. Girls Day (Hinamatsuri) in Japan is celebrated on March 3. On the celebration day, dolls (hina-ningyō) representing the Emperor, Empress, attendants, and musicians in traditional dress are displayed on a red carpet in the house or shrine. Beautiful dolls became a necessary part of the celebration, but only noble families can afford them even today (Murguia, 2011). In the Edo period (1603 -1868) the tradition Tsurushibina was started by families not having enough money to buy dolls, wishing to celebrate their daughters (Tsurushi Encyclopedia website, 2017). Using their kimono fabric scraps, grandmothers, mothers, made little dolls, and hang them in the house, wishing well-being for the baby-girl. Tsurushibina, literally translated as a "hanging dolls". Variety of little dolls are symbols associated with the girl prosperity, protection from evil, women fertility, easy birth and a nice partner (Mihara, 2009). There are several classifications of Tsurushibina decoration. Firstly, there are three varieties made in 3 areas of Japan: Sagemon, Tsurushi Kazari and Kasafuku from Fukuoka, Shizuoka and Yamagata accordingly. In previous research, all decoration elements from the three places of origin were classified by categories: flowers, human shape, food, animals, household items and toys (Mihara, 2009). Current research includes only botanical and zoological motifs of Tsurushibina decoration from Inatori, since we are focusing on the connection of the decoration with the natural environment (Table 1). We suggest a new classification based on the supposed origin of the auspicious meaning: shape, color, sound (homophones) and folklore, augmented by the analogy with the quality of the object. This classification helps to trace the connection of the observation of nature as a source of inspiration of the decoration (Table 1) and as a result it's "biocultural code".

Among Japanese crafts, Tsurushibina did not receive official cultural heritage status due to its folklore character. It has a little research coverage in Japan and not described in the English literature.

Following this background, we research the traditional Japanese craft of Tsurushibina in Inatori district of Higashiizu town, Japan. What is the Tsurushibina craft practice of Inatori and what meaning does it have in the context of local community development? To answer this question, we put the following research goals.

1. To investigate the origin of Tsurushibina craft of Inatori and its meaning, document it's characteristics and relation to natural environment, it's "biocultural code"

2. To learn the process of development of Tsurushibina preservation movement in Inatori, its main stakeholders and results for local revitalization

3. Consider the possibility to use the Tsurushibina craft for contemporary Japanese community sustainable development on local level

\subsection{Method}

\subsection{Location}

Inatori district is a part of Higashiizu town, located on eastern part of Izu peninsula. The population of the Inatori district consisted of 6302 people as of 2014 , which is 300 people less compared to 2012. Looking at the population composition ratio of Higashiizu town by 
age classification, the youth population ratio is about $10 \%$, the productive age population is about $50 \%$, the percentage of an elderly population is $40 \%$ (Higashiizu town website, 2018).

\subsection{A short history of the area development}

Izu peninsula has an advantageous spatial position for developing its tourism industry further. It is located rather close to Tokyo (Higashiizu town in $160 \mathrm{~km}$ ) and connected with it by the Izu Kyūkō train line since 1961. Inatori, little fisherman's village, during Edo era, supplied huge stones to build Edo castle. After World War 2 during the time of the rapid economic growth, Inatori became a hot spring resort (onsen), overflowing with profit from mass tourism. By that time, more than 70 percent of the local population had been involved in the tourism industry. Since the economic bubble burst in 1992, the local hotel business association began to suffer losses. In 1990 there were more than 700 thousand visitors, until 2007 this number decreased to only 50 thousand people (Nogata, 2011). To revitalize Inatori district, the local Tourism Association and the town office started to put various efforts into area resource exploration and development. At that time, a local Women Association leader set her goal - to learn the Tsurushibina craft from elders to revive their tradition. It evoked a huge resonance among local people and in the media. The Tourism association, following the success of the campaign, decided to use a Tsurushibina decoration exhibition during the Girls Day (March 3rd) festival, to attract customers to the area. After few years, the Inatori district became famous in Japan as one of three places of origin of Tsurushibina decoration. Craft practice spread all over the country, attracting more and more customers to Inatori. The development of the Tsurushibina decoration preservation movement and as a result, a tourism based on it is the subject of this research and will be described below.

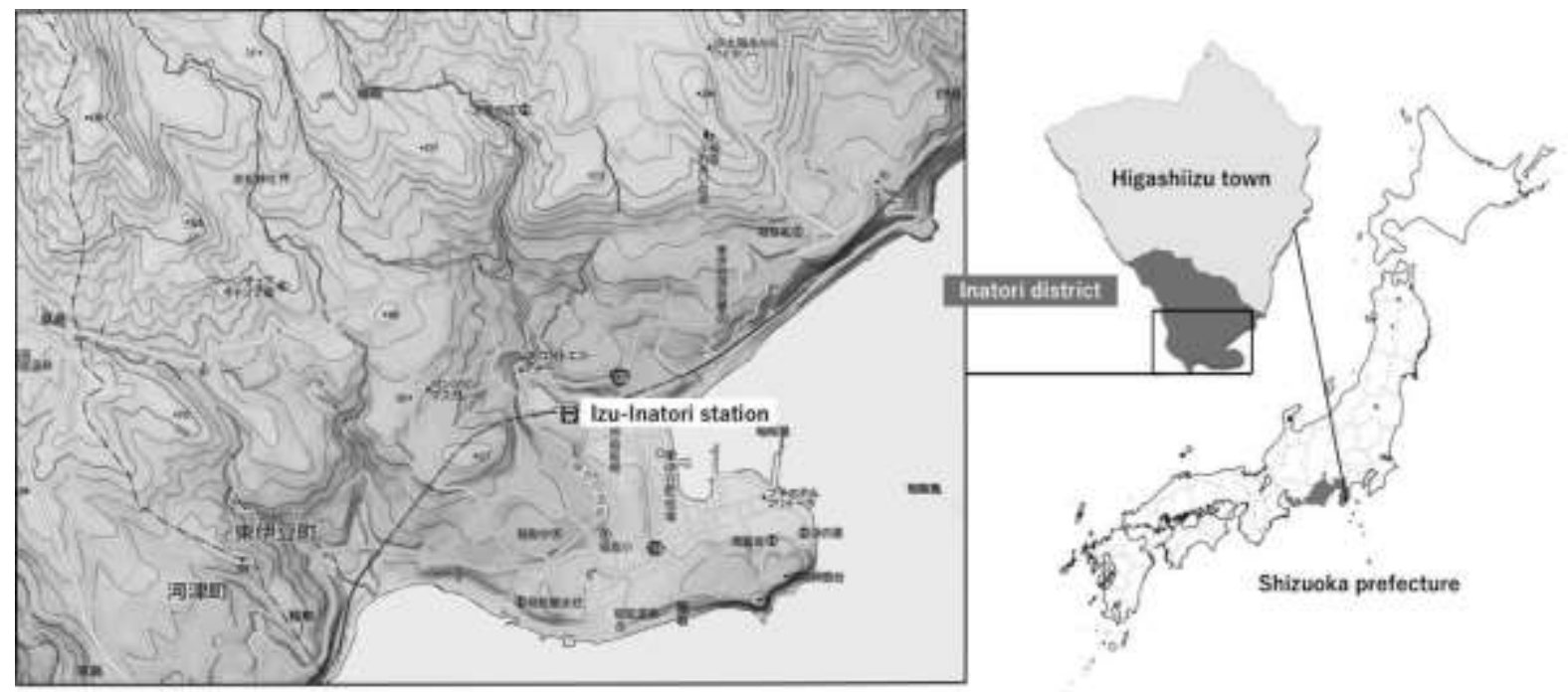

Fig.1. Study area: Inatori district located in Higashiizu town, Shizuoka prefecture, Japan.

(Source: Yahoo Japan maps)

\subsection{Research Method}

To complete the research, we used semi-structured interviews, observation, and manual coding supported by literature review. The field trips to the research site were held during the spring Girls Day Festival celebration from 22nd to 25th of February 2017 and after the Boys Day Festival from the 22nd until the 25th of May 2018. The average time of the interview was 40 minutes. To get access to local informants, we used a snowballing technique, firstly asking the craft shop owners about anyone related to a craft revival movement. During first interview session we couldn't get access to the people who worked in craft preservation movement in the past, but reached the saturation during additional interviews in May 2018, when talked to the founder of the craft preservation movement, Mrs. Ota. During the field expedition, the observations of Inatori district were made by walking in the area with a photo camera and an audio recorder. We documented the display of the craft in local shops and houses. Interviews were held at the site in Japanese. In total 16 people were interviewed with their permission. Interviewees include practitioners of the craft, local residents, shop owners, city officers, business and hotel associations members and fishermen. Interviews were later augmented by field notes and transcribed. The people were asked about their involvement in crafting activities, their motivations, the sources of information and materials for the craft, the symbolic meaning and origin of the meaning of Tsurushibina decorations, their attitudes toward the crafting activity, and the development of the Inatori district.

\subsection{Findings}

\subsection{Characteristics of the Tsurushibina decoration}

Tsurushibina decoration is a number of small dolls, sewn from silk shreds, suspended alternately on the threads fixed on the frame (refer to Figure 2). The traditional number of dolls differs in three places of origin in Japan. In Inatori eleven dolls on five threads 
decoration. Traditionally, there are two decorations on one display. The decoration elements and their use also vary according to its area. The example of the special element in Inatori decoration is the Kinme fish (Figure 2, b), which is the special product of this area.

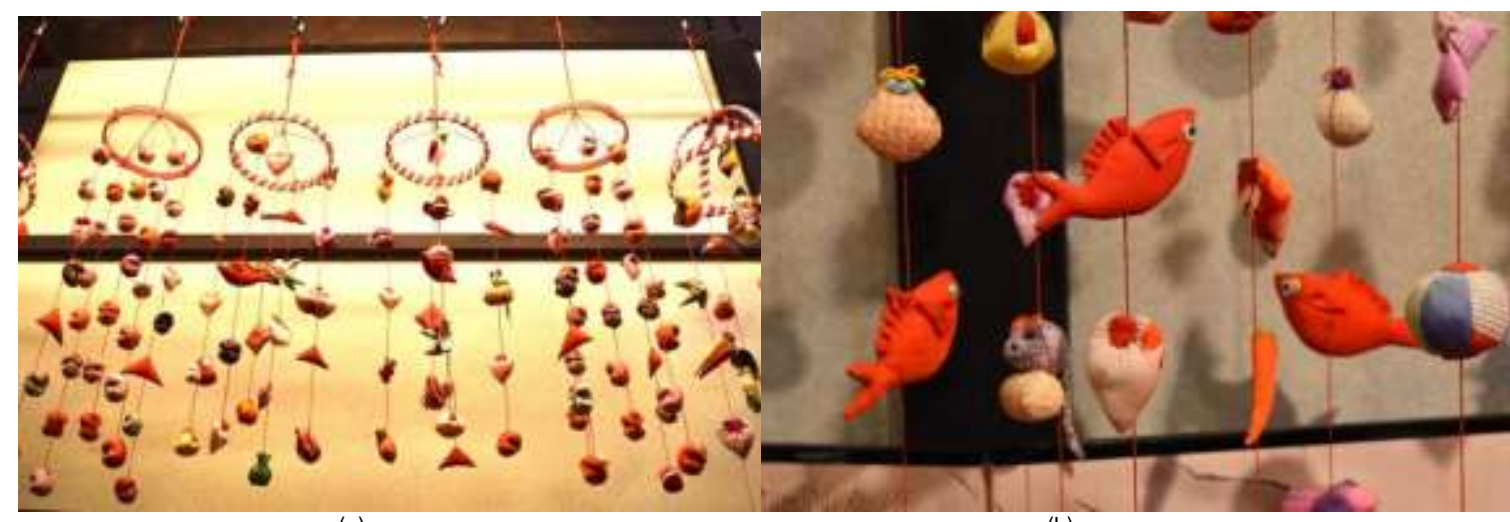

(a)

(b)

Fig. 2. (a) Traditional Tsurushibina decoration on display in Inatori Tsurushibina Cultural Park. (b)Special product of the area - Kinme fish is included in the decoration.

(Source: Mariia Ermilova, 2017).

The official pamphlet of the Tsurushibina hanging doll in Inatori list up 34 elements and defines them as "the most popular" elements in Inatori area without reference to any source, which is caused by folklore character of knowledge and its little documentation.

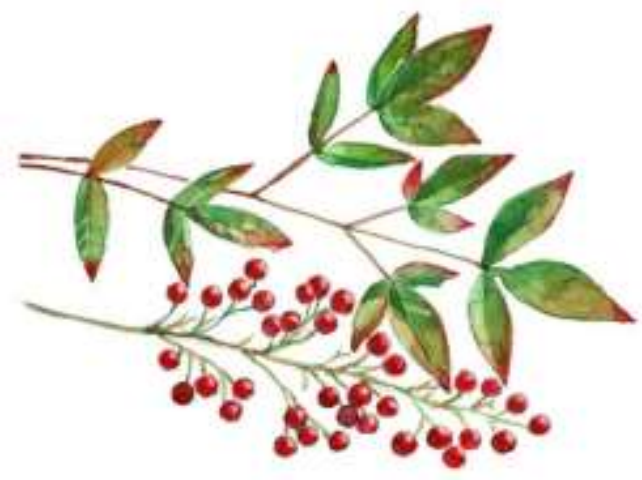

(a)

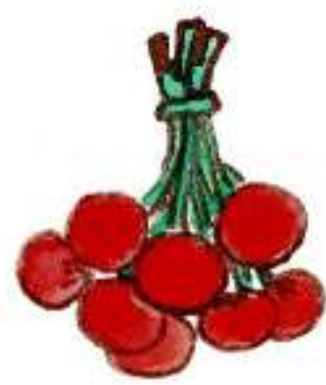

(b)

Fig.3. (a) Nanten plant (Nandina domestica) and (b)Tsurushibina decoration element, imitating the berries (Source: Mariia Ermilova).

\subsubsection{Tsurushibina meaning}

Hanging dolls are the auspicious symbols, created with the wish for the baby girls' prosperity, protection from evil, women fertility, easy birth, a nice partner and other blessings. The origin of the meaning of decoration is partly based on oral folklore closely related to Shinto and Buddhist beliefs and mythology as well as the observation of nature. For example, "have many babies like a rabbit", "become beautiful like a cherry flower", etc.

\subsubsection{Tsurushibina meaning origin}

The connection between nature motif and symbolic meaning was evocated by three main factors: sound (play of words), color, shape, and wish for the analogy with the quality of the object. From Table 1 we can see that many edible plants become symbols for their medicinal and nutrition properties, while the animals are becoming the symbols for their skills and virtues. Let us illustrate the categories of their auspicious meaning derivation. In China, the word for "fish" (yu) was homophonous with the words for "extra" (yu) and, as a consequence, came to mean "good fortune and the flourishing of descendants." Since they produce many eggs, fish became the symbol of fertility and was a popular design motif in Japan from the ancient period. Shrimp (ebi), written with the characters 海老 (Ch. hailao; literally "elder of the sea"), came to connote long life (Shirane, 2012). Red berries of Nanten (Figure 3) is a plant commonly known as Nandina, "heavenly bamboo" or "sacred bamboo". In Japan as well as China Nandina symbolizes sacred celebration and means "south heaven," because of its association with the lucky gods. The reading is homophonic to "nan wo tenzuru", meaning hardship reversal. Additionally, dried berries are used to cure a cough in traditional Chinese medicine. Some of the animals have a round shape (fuku) which is homophonic to a good fortune - "fuku", for example owl, sparrow. Clamshells are symbols of fidelity since two valves make a unique match. Tsurushibina decorations are dominated by red color, which is believed to repel evil spirits. Some of 
the ornamental elements are associated with proverbs about the color of autumn fruits, bringing health. For example, "When persimmon turns red doctors become blue". The season when fruits are eaten results in fewer patients so that doctors worry about losing their jobs and get pale faces. It has similarity with the English phrase "An apple a day keeps the doctor away".

Table1. Classification of Tsurushibina decoration by origin of its auspicious meaning by authors based on literature review and interviews.

\begin{tabular}{|c|c|c|c|c|c|c|c|}
\hline & $\begin{array}{l}\text { Classification element by origin of } \\
\text { auspicious meaning }\end{array}$ & Shape & Color & $\begin{array}{l}\text { Sound } \\
\text { (Homophones) }\end{array}$ & $\begin{array}{l}\text { Edible or } \\
\text { medicinal } \\
\text { use }\end{array}$ & $\begin{array}{l}\text { Folk tales } \\
\text { and } \\
\text { religion, } \\
\text { proverb }\end{array}$ & $\begin{array}{l}\text { Analogy } \\
\text { with the } \\
\text { quality } \\
\text { of the } \\
\text { object }\end{array}$ \\
\hline & \multicolumn{7}{|l|}{ Element of decoration } \\
\hline \multicolumn{8}{|c|}{ Botanical } \\
\hline 1 & Peach & $\mathrm{v}$ & $\mathrm{v}$ & & $\mathrm{v}$ & $\mathrm{v}$ & $\mathrm{v}$ \\
\hline 2 & Mandarin Orange & & v & & $\mathrm{v}$ & & \\
\hline 3 & Red pepper & & v & & v & & v \\
\hline 4 & Carrot & & v & & v & & \\
\hline 5 & Radish & & v & & v & & \\
\hline 6 & Bifurcated radish & v & v & & v & v & \\
\hline 7 & Strawberry & & v & & v & & \\
\hline 8 & Rice & & & & v & & \\
\hline 9 & Persimmon & & $\mathrm{v}$ & & $\mathrm{v}$ & $\mathrm{v}$ & \\
\hline 10 & Peach flower & & & & v & & \\
\hline 11 & Sakura cherry flower & & & & & & $\mathrm{v}$ \\
\hline 12 & Plum flower & & $\mathrm{v}$ & & $\mathrm{v}$ & & v \\
\hline 13 & Physalis lantern & $\mathrm{v}$ & v & & v & & v \\
\hline 14 & Platycodon(bellflower) & & & & v & & v \\
\hline 15 & Nanten (sacred bamboo) & & & $\mathrm{v}$ & v & & \\
\hline \multicolumn{8}{|c|}{$\begin{array}{l}\text { Zoologica } \\
\text { I }\end{array}$} \\
\hline 1 & Monkey & & & $\mathrm{v}$ & & $\mathrm{v}$ & $\mathrm{v}$ \\
\hline 2 & Owl & v & & v & & & \\
\hline 3 & Dog puppy & & & & & & v \\
\hline 4 & Dog & & & & & & \\
\hline 5 & Turtle & & & & v & v & v \\
\hline 6 & Shrimp & & v & v & v & & \\
\hline 7 & Clam (Mollusk) & v & & & v & & v \\
\hline 8 & Golden fish & & v & v & & & \\
\hline 9 & Splendid Alfonsino & & v & & v & & \\
\hline 10 & Chicken & & & & v & & v \\
\hline 11 & Dove & & & & & v & v \\
\hline 12 & Sparrow & & & & & & v \\
\hline 13 & Japanese bush warbler & & & & & & v \\
\hline 14 & Rabbit & & & & & $\mathrm{v}$ & v \\
\hline 15 & Cicada & & & & & & v \\
\hline 16 & Butterfly & & & & & & v \\
\hline 17 & Mouse & & & & & v & v \\
\hline 18 & Crane & & & & & $\mathrm{v}$ & $\mathrm{v}$ \\
\hline
\end{tabular}

\subsubsection{Connection with environmental knowledge}

Most of the fruits and vegetables used as decoration motive are commonly used in daily life for food and medicine (Table 1). The main plant figure used for Girls Day celebration, and Tsurushibina correspondingly, is a peach tree. Flowers, seeds, fruits and leaves of the peach tree are used in Chinese medicine for woman body purification and various disease treatment. The most valued healing properties of peach seed in traditional Chinese medicine are its effect of promoting blood circulation. In particular, it can be applied to treat scarce menstrual flow or even absence of menstruation in women. The numerous blossoms of peach trees are said to have a reproductive quality, providing the basis for the folkloric notion that the conception of a large number of children may increase the level of happiness within a marriage (Murguia, 2011). This is how the peach tree is associated with the female body and her reproductive functions. The good example is a red pepper. It drives away insects, so it supposed to drive away undesirable lovers from young women.

Folklore content is highly filled with centuries of knowledge from the interaction with the local environment and contains information of the best use of local products. The Tsurushibina craft reveals the deep connection of people to local environment creating a "biocultural code" that contains traditional ecological knowledge (Ermilova, 2017). It can be considered as a craft-embodied expression of traditional knowledge of the Japanese people. 


\subsubsection{The traditional way of transmission}

The Tsurushibina hanging doll decoration in Inatori traditionally has been made by female family members to bless a baby girl in the house. It is important to say, that Inatori's local craftsmen put an additional value to family members-made tradition because it emphasizes - eternal values like parent-child love and devotion. In Sakata, Tsurushibina was traditionally located in Buddhist temples and served as objects of prayer for a child conception. Kasafuku hanging doll decoration contained the elements of auspicious sexuality, supposed to bring desired children to the farmer's families. In Yanagawa, the Sagemon hanging doll decoration was traditionally brought by the community to the newborn baby house for celebration (Fujita, 2004).

Ota san mentioned in the interview that in old times, as all protective amulets, the decorations were burned in a Dondonyaki traditional fire around New Year time. Mihara (2009) brings the example of the similar tradition of burning the decoration when the daughter got married. This explains the scarcity of preserved decoration and it's decline in the after chaos of World War II, also connected with the shift from traditional family to the nuclear type.

\subsubsection{The development of new craft on the base of traditional}

For 10 years Inatori craftswomen are creating Boy's Day decoration, which is exhibited during the Children Day or Boys Day, celebrated May 5th in Japan. We asked for the reason to create a new decoration for boys. Mrs. Mori referred to inability to use the traditional decorations for Boys Day in the urban context and need for new, compact celebration decorations, expressed by customers.

\subsection{Sustaining traditional craft movement and economic revitalization by tourism}

\subsubsection{Origination of craft in Inatori}

Local people have no firm explanation of how Tsurushibina was originated in the Inatori area. Some interviewees said that the Inatori port was used as a rest place during the tropical storms in Edo era and some boats from the capital were paying off their stay not only by money but by some luxury goods, like the Hina Dolls. Also, the Inatori area supplied the stones for the Edo castle, which created the constant exchange with Edo city. At the same time Inatori was a big fishing port and remained famous for its Kinme fish until nowadays. Hina Dolls bring the Girls day celebration to the area and following invention of a "cheap" celebration by Tsurushibina Hanging Dolls.

\subsubsection{Decline of craft practice}

After the World War II the craft was in decline. As mentioned, it was treated like an amulet and was presumably disposed of after use. Moreover, the new generation moved to growing cities and the tradition passed by inheritance was interrupted. An important aspect was played by a new ideology of alienation from everything old, especially among women who, with the arrival of industrialization, were emancipated from the slavery-like labor at traditional Japanese family (Creighton, 2001), (McDowell, 1999).

\subsubsection{Premises for the craft revival}

Kinunokai craft workshop director Sachie Mori (personal communication, February 2017) said about the start of craft practice revitalization in 1993, describing how the spirit of the time itself contributed to a successful wave of interest in this handicraft:

"The timing was perfect. In the situation of economic decline, people remembered about resource saving, which was Japanese ideology long time ago. It is expressed in the Japanese words "mottainai", conveying a sense of regret concerning waste of useful resources. The whole world was speaking about the global ecological crisis, people started recycling. Tsurushibina craft fit well with the new paradigm of environmental consciousness and sustainable society, and the campaign had a success".

\subsubsection{Revitalizing the craft practice by transmission of knowledge}

Mrs.Ota, the founder of the Tsurushibina preservation movement (refer Table 2), saw the Tsurushibina at her neighbor's house when she was asked by her grandmother to bring a celebration gifts to a newborn baby (personal communication, May 2018). Since then she got fascinated with the tradition and started to collect information about the craft. Later, when she became a local Women Association leader, she got an opportunity to act. She described the events: "When I became the Women association leader, I put the goal to revitalize the craft of that area. We formed an initiative group to learn from elders and visited them every 2 days for 2 months. We learned the Tsurushibina with full dedication. After that, we were able to hold some workshops for large members. It attracted about 60 ladies of the younger generation from our area." After the successful series of workshops, Women Association held the first exhibition of Tsurushibina, which had a great success. Continuing the community research work with the craft, Mrs. Ota organizes the trips to the other two places of origin of the decoration in Japan: "We went to the Yanagawa to research the decorations and to see the difference from Inatori. There we realized that the decoration exhibits are very effective to bring lots of tourists to the area."

After 2 years of successful works by the Women Association, the Hotel Association take an initiative to make the exhibition and suggested its support.

Table 2: The history of Tsurushibina craft preservation in Inatori from the interviews with craft movement leaders

\begin{tabular}{rrl}
\hline Date & & Steps of the preservation movement \\
\hline & 1993 April & Mrs. Ota became a leader of local Women Association (Fujinkai, part of local Neighborhood Association) \\
May, June & Mrs. Ota and some members of the association visited to listen to elder about how to \\
May & Workshop on hanging decorations held at Women Association (led by Mrs. Ota) \\
Nov & Show Tsurushibina which was created by the women association at a Cultural festival of Inatori \\
1994 & Workshop on Tsurushibina decorations held at Women Association
\end{tabular}


1997 TV broadcasting company is picking up the activity of local women in Inatori

1997 Mrs. Ota and some members visited Fukuoka to seek the significance of Inatori's Tsurushibina

1998 Inatori Hotel Association held the first Tsurushibina hanging doll decoration festival

Assembling the Tsurushibina Decoration Preservation Group

1999 Working with the old decorations to collect information on traditional shapes and meanings with Tsurushibina Decoration Preservation Group Conflict between preservation and commercial use ideologies, separation

2000 Group of women, who have worked in the Inatori Hotel Association's production room led by Ms. Mori make a "Kinunokai" studio

2002 "Cultural park of Tsurushibina" hall opened by Inatori Hotel Association

2004 Tsurushibina House Open (Tomioka House is closed)

2007 Open the workshop of making silk Tsurushibina decoration at the "Kinunokai". Principle to use the traditional material (silk).

Nowadays Two studios are open for visitors to learn the craft. Number of local shops are selling the materials and the ready Tsurushibina decorations. Craft exhibited in all local shops and hotels during the year. There is no preservation committee for the craft and coordinated efforts for its preservation.

\section{The conflict between the preservation and commercial use ideologies}

The founder of Tsurushibina preservation movement in Inatori wanted to promote it as a local tradition, but some other members wanted to sell it and use as a tourist attraction because Inatori was facing the economic crisis so that people can't do volunteer work. It resulted in a conflict and discoordination in the preservation movement. Mrs.Ota, founder of the movement talks about it with the mixed feelings: "I don't know if I did a good thing or not when I started the revival of decoration in Inatori. I also don't judge the people who sale the decorations. I just feel the pain for the local pride of Inatori. I think, that we should have tried to preserve the Tsurushiina decoration as a tradition of this place first of all."

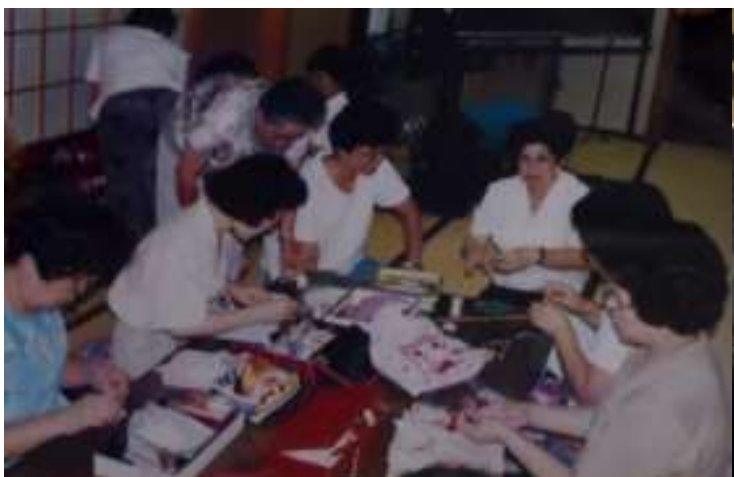

(a)

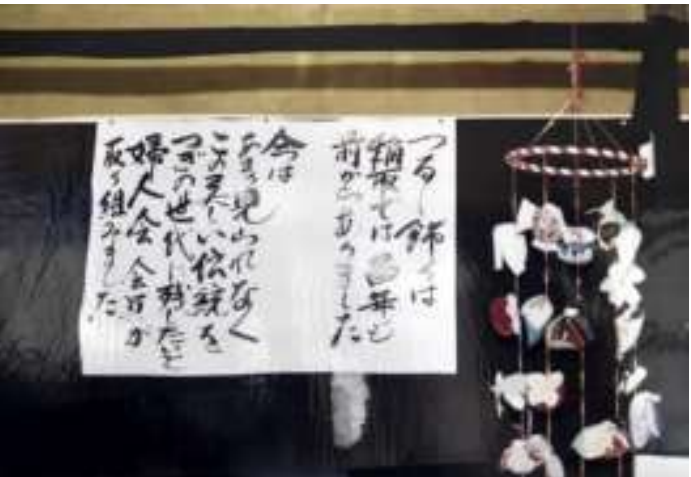

(b)

Figure 2. Pictures from archives of Mrs.Ota: (a) Gathering of local women in Inatori for Tsurushibina craft learning in 1993, (b) - The motto of the first revived craft exhibit: "Tsurushibina craft has been existing in Inatori from long time ago. Women Association made the Tsurushibina Craft exhibition in Inatori for transmission of this unique and almost forgotten knowledge to next generations".

\subsection{The current state of the craft knowledge and community involvement in preservation and tourism}

In recent years about 900,000 customers are coming to Higashiizu town during the year. They see the Girls Doll Festivals, participate in the craft workshops and buy souvenirs. They enjoy local food and hot springs. The owner of a shop, Ms.Okada who is making Tsurushibina for sale with her daughter, said in her interview: "There is a family, who is coming every year to my shop. They buy one hanging doll thread each year and they told me this would be already eight one. I was moved by their faithfulness. Their coming for 8 years to see me and even a little girl of this family calls me the grandmother!" (personal communication, February 2017). That indicates the success of community-based tourism in the area.

Higashiizu city office conducted a web survey (2013) about the most known reasons to go to Higashiizu. Respondents were 1000 people from Tokyo metropolitan area and haven't been to Higashiizu. Tsurushibina decoration (412) was mentioned by respondents on the second place after the hot spring (689).

Tsurushibina craft has a high visual appeal, fascinating viewers with their numerous details and narrative structure. This kind of appeal is successful in attracting visitors. Local craft association now invented new craft items for Boys' Day and other traditional celebrations. Along with contemporary needs, as mentioned above, it shows the demand from the tourism industry. Local craftsmen teach children in school once a year to transmit the knowledge of Tsurushibina to next generations, but, probably, it is not enough. Tourism industry can help to sustain the community economically, but development has to be done very carefully (Hribar, Bole, \& Pipan, 2015). In case of Inatori, the lack of coordination and agreement lead to the dissipation of the preservation group. In the communities around the world the preservation of their heritage is becoming a challenge, and to improve the situation the initiatives need to be established to engage the community in safeguarding their intangible cultural heritage (Bakar, Osman, Bachok, \& Ibrahim, 2014), (Kolay, 2016). The effort of Inatori's locals will again be needed to revive the living tradition of the Tsurushibina craft from the current state of commercial commodity. Nowadays the Trushibina craft practice in Inatori seems to be occupied by professionals and not practiced by local residents as a living tradition. The process of documentation of traditional knowledge contains the conflict between "preservation" and "protection", since there is a risk of exploitation of the traditional cultural expressions, when they become available to third parties. At the same time, the craft with its folklore character continue to develop and change shaped by the needs of its practitioners and admirers, going beyond the limitations imposed by the term cultural heritage. 
In Japan the conservation of Intangible Heritage receives a broad support and is regulated by Law for the Protection of Cultural Properties (1950). For instance, a special category of Living National Treasure is given to people, who transmitting Intangible Heritage practices. Despite the variety of support for Cultural Heritage, The Tsurushibina craft remains to be the folk art, belonging to people, without a patented technology. Since there is a variety of elements and combinations, not restricted by rules, it is difficult to register it as a product. It is up to the people of the area, where the craft originated, how to document, preserve the traditional craft and how it will be transmitted to the next generation.

\subsection{Research limitations}

This research in focused on Tsurushibina decoration craft of Inatori District of Higashiizu Town, which is only one of three places in Japan, where the craft practice originated. Aiming to reveal the origin of craft motives connecting it to natural environment research reviews only the meanings of botanical and zoological symbols of decorations, excluding the toys instruments, etc.

The key stakeholders of the craft revitalization movement were chosen based on their role and participation in the movement in the past and as the most prominent at the moment. For a detailed evaluation of the level of involvement in the craft practice by Inatori citizens in general, a survey research will be needed.

\subsection{Future research implications of Tsurushibina craft in the context of sustainable community development}

The Tsurushibina craft has multiple dimensions, relating to different aspects of community sustainable development. Future research may include the areas, collected in Table 3.

Tsurushibina craft can be applied for environmental education, raising awareness of the locality, as an activity increasing social capital, enhancing the family institution, as well as empowering women.

The multielement and diverse character of the craft creates a broad possibility for the participatory creation of work.

Table 3. The actuality of Tsurushibina craft in the context of sustainable community development and implications to its use and future research

Tsurushibina Craft Feature
Creates a heritage in the family, unite the
generations with emotional bonds
Creates the connection with cultural identity by
learning cultural symbols
Contains the "biocultural code" - environmental
knowledge
Express the locality, specialty of place
Multiple variations of patterns, diversity of
expressions
Compound structure, variety of expressions and
levels of difficulty
Unite the women in the family and community

Creates opportunity for local business

\begin{tabular}{ll} 
Aspect of Sustainability & Actuality (problem in society) \\
\hline Social & Nuclear family, loneliness of elderly people \\
Social, Cultural & Lack of cultural Identity between the megapol \\
Environmental & Decreasing environmental knowledge \\
Local culture preservation & Urbanization, placelessness \\
Equality, Diversity & Low acceptance of diversity in society \\
Participation & Low participation in local community activities \\
$\begin{array}{l}\text { Women empowerment } \\
\text { Women empowerment, } \\
\text { economical } \\
\text { Preservation of local heritage }\end{array}$ & Gender inequality \\
\end{tabular}

\subsection{Conclusion}

The meaning of Tsurushibina decoration is based on oral folklore and observation of nature. Tsurushibina craft reveals the deep connection of people to the local environment, creating a "biocultural code" containing the traditional ecological knowledge, which can be "read". Tsurushibina craft knowledge preservation in Inatori started as a citizen movement and was later integrated into the tourism industry, resulting in conflict between local preservation committee members and leading to a discoordination of the preservation of this craft. Tsurushibina craft contributes to community development economically, attracting customers for local business, used in community-based tourism.

The narrative history of the Inatori district's Tsurushibina craft reveals the struggle between preservation and economic use of traditional craft and brings insights for further research. Having the ability to unite people in a creative expression with their natural environment, their ancestors, and descendants, Tsurushibina craft has the potential to contribute to the sustainable community development in all three dimensions: social, economic and ecological.

\section{References}

Bakar, A. A., Osman, M. M., Bachok, S., \& Ibrahim, M. (2014). Analysis on Community Involvement Level in Intangible Cultural Heritage: Malacca Cultural Community. Procedia - Social and Behavioral Sciences, 153, 286-297. https://doi.org/10.1016/J.SBSPRO.2014.10.062

Berkes, F., Colding, J., \& Folke, C. (2000). Rediscovery of traditional ecological knowledge as adaptive management. Ecological Applications, 10(5), 1251-1262. https://doi.org/10.1890/1051-0761(2000)010[1251:ROTEKA]2.0.CO;2 
Cetinkaya, G. (2009). Challenges for the Maintenance of Traditional Knowledge in the Satoyama and Satoumi Ecosystems, Noto Peninsula, Japan. Human Ecology Review. Society for Human Ecology. https://doi.org/10.2307/24707732

Chang, S. E. (2015). The Danshui River Cultural Ecosystem as the Amis Tribal Landscape: An Asian Green-grassroots Approach. Procedia - Social and Behavioral Sciences, 170, 463-473. https://doi.org/10.1016/J.SBSPRO.2015.01.010

Creighton, M. (2001). Spinning Silk, Weaving Selves: Nostalgia, Gender, and Identity in Japanese Craft Vacations. Japanese Studies, 21(1), 5-29. https://doi.org/10.1080/10371390120048722

Denan, Z., Majid, N. H. A., \& Arifin, N. (2015). Ingenious Malay Wood Carving as Daylight Filtering Devices. Procedia - Social and Behavioral Sciences, 201, 182-190. https://doi.org/10.1016/J.SBSPRO.2015.08.167

Dragin, A., Krusmetra, M., Jeroscenkova, L., Pivac, T., \& Rivza, B. (2015). Craft as a Business Development Challenge: Latvian and Serbian Craftsmen's Views. Procedia - Social and Behavioral Sciences, 185, 76-83. https://doi.org/10.1016/J.SBSPRO.2015.03.433

Egizbayeva, M., \& Zhumatayev, R. (2014). Decorative and Applied Art of the Kazakhs Tarbagatai. Procedia - Social and Behavioral Sciences, 122, 236-239. https://doi.org/10.1016/J.SBSPRO.2014.01.1334

Ermilova, M. (2017). A Traditional Japanese Craft Helps Maintain and Restore Biocultural Knowledge and People's Connection with Nature. Langscape Magazine, 6(2), $31-35$

Fujita J. (2004):Hina no Syonai Nito monogatari (The story of the Hina Doll) Spoon book, p.252-261

Higashiizu Town (2013) Higashiizuchō kankō shinkō keikaku (Higashiizu Town Tourism Promotion Plan). Retrieved from http://www.town.higashiizu.shizuoka.jp/bg/town_gov/upload/knk_kanko-plan.pdf

Honda, T., Ueda, H., Ozaki, M., Inachi, S., \& Sakaki, A. (2015). Preservation of Daiki Old Elementary School Building as the Symbol of the Regional Environmental Sustainability, Susami Town, Wakayama, Japan. Procedia - Social and Behavioral Sciences, 184, 365-371. https://doi.org/10.1016/J.SBSPRO.2015.05.104

Hribar, M. Š., Bole, D., \& Pipan, P. (2015). Sustainable Heritage Management: Social, Economic and Other Potentials of Culture in Local Development. Procedia - Social and Behavioral Sciences, 188, 103-110. https://doi.org/10.1016/J.SBSPRO.2015.03.344

Kolay, S. (2016). Cultural Heritage Preservation of Traditional Indian Art through Virtual New-media. Procedia - Social and Behavioral Sciences, 225, 309-320. https://doi.org/10.1016/J.SBSPRO.2016.06.030

MacEachren, Z. (2000). Crafting as a Practice of Relating to the Natural World. Canadian Journal of Environmental Education (CJEE) (Vol. 5). Canadian Journal of Environmental Education. Retrieved from https://cjee.lakeheadu.ca/article/view/309/236

Maffi, L., \& Dilts, O. (2014). An Introduction to Biocultural Diversity. Biocultural diversity toolkit. Terralingua.

Maidment, J., \& Macfarlane, S. (2011). Crafting Communities: Promoting Inclusion, Empowerment, and Learning between Older Women. Australian Social Work, 64(3), 283-298. https://doi.org/10.1080/0312407X.2010.520087

McDowell, J. (1999). Japanese women and their connection to the craft movement and craft production in Japan. Lambda Alpha Journal, 29, 12-28.

Moro, E. (2016). The Mediterranean Diet from Ancel Keys to the UNESCO Cultural Heritage. A Pattern of Sustainable Development between Myth and Reality. Procedia - Social and Behavioral Sciences, 223, 655-661. https://doi.org/10.1016/J.SBSPRO.2016.05.380

Murguia, S. J. (2011). Hinamatsuri and the Japanese Female: A Critical Interpretation of the Japanese Doll Festival. Journal of Asia Pacific Studies, 2(2), 231-247.

Nogata, H. (2011). Izu chiiki no kankou no genjou to kanousei. Shizuokadaigaku keizai kenkyuu (Current situation and possibilities of tourism in the Izu area, Shizuoka University Economic research), 15(4), 133-153. Retrieved from https://ir.lib.shizuoka.ac.jp/bitstream/10297/5738/1/15_4-0133.pdf

Shirane, H. (2012). Japan and the culture of the four seasons: nature, literature, and the arts. Columbia University Press.

Shuaib, A. A., \& Enoch, O. F. (2014). Integrating the Malay Traditional Design Elements into Contemporary Design: An Approach towards Sustainable Innovation. Procedia - Social and Behavioral Sciences, 129, 59-67. https://doi.org/10.1016/J.SBSPRO.2014.03.648

Silah, S., Basaree, R. O., Isa, B., \& Redzuan, R. S. (2013). Tradition and transformation: the structure of Malay woodcarving motifs in craft education. Procedia - Social and Behavioral Sciences, 90, 823-831. https://doi.org/10.1016/j.sbspro.2013.07.157

Statistics Bureau of Japan (2017). Statistical Handbook of Japan Retrieved from: http://www.stat.go.jp/english/data/handbook/index.html

Tsuchiya, K., Aoyagi, M., Okuro, T., \& Takeuchi, K. (2014). The potential of, and threat to, the transfer of ecological knowledge in urban areas: The case of communitybased woodland management in Tokyo, Japan. Ecology and Society. https://doi.org/10.5751/ES-06369-190225

Tsurushi Encyclopedia website (2017) Retrieved from http://www.tsurushi.jp/origin/index.html

Tzanidaki, D., \& Reynolds, F. (2011). Exploring the meanings of making traditional arts and crafts among older women in Crete, using interpretative phenomenological analysis. British Journal of Occupational Therapy. https://doi.org/10.4276/030802211X13125646370852

World Intellectual Property Organization (2017). Documenting Traditional Knowledge - A Toolkit. Retrieved from http://www.wipo.int/edocs/pubdocs/en/wipo_pub_1049.pdf 